\title{
Diskurusus Kebijakan Publik Model Incremental
}

\author{
Harry Fajar Maulana ${ }^{1}$, Sry Mayunita ${ }^{2}$, Hastuti $^{3}$, Andy Arya Maulana Wijaya ${ }^{4}$ \\ 1Ilmu Komunikasi, Universitas Muhammadiyah Buton \\ Email: harryfajarmaulana@gmail.com \\ 2Ilmu Pemerintahan, Universitas Muhammadiyah Buton \\ Email: srymayunita.ita@gmail.com \\ 3Ilmu Komunikasi, Universitas Muhammadiyah Buton \\ Email: hastutituwo@gmail.com \\ 4IImu Pemerintahan, Universitas Muhammadiyah Buton \\ Email: andy.arya@umbuton.ac.id
}

\begin{abstract}
Abstrak; Salah satu kesulitan dalam kebijakan publik adalah efisiensi waktu, dimana kebijakan akan selalu melibatkan waktu, tenaga dan materi yang cukup panjang. Artikel ini bertujuan untuk memberikan beberapa perspektif untuk medeskripsikan usaha pembuatan kebijakan publik dengan sederhana. Melalui pendekatan inkremental, artikel yang didasarkan pada studi pustaka ini mencoba mengurai berbagai persepektif tentang kebijakan publik model inkremental. Maka, artikel ini menemukan bahwa model Inkremental dapat dinyatakan sebagai sebuah model kebijakan yang dilakukan dengan mendesain ulang kebijakan yang ada namun masih dalam koridor rangka utama kebijakan asalnya. Model Inkremental dilakukan untuk menghadapi masalah yang membutuhkan penanganan dengan waktu yang cukup singkat. Tantangannya adalah dalam model kebijakan ini, seringkali membutuhkan ketelitian aktor kebijakan dan pilihan-pilihan alternatif yang tidak mudah.
\end{abstract}

Kata Kunci: Kebijakan Publik, Inkremental, Diskursus 


\section{Latar Belakang}

Pengambilan

keputusan

bersangkut paut dengan masalah pilihan yang dirumuskan oleh seorang aktor atau sejumlah aktor dalam memecahkan suatu persoalan atau masalah publik. Secara umum pengertian pengambilan keputusan adalah teknik pendekatan yang digunakan dalam proses pengambilan keputusan atau proses memilih tindakan sebagai cara pemecahan masalah. Salah satu pendekatan yang dapat dipakai untuk memberikan alternatif solusi bagi suatu masalah adalah pengambilan keputusan dengan pendekatan inkremental. Lahirnya Model Inkremental tidak terlepas dari kritik terhadap model atau Model rasionalitas komprehensif yang dinilai tidak cocok lagi untuk menyelesaikan persoalan-persoalan publik. Adanya ketidak cocokan ini kemudian lahirlah Model inkremental.

\section{Model inkremental pada}

hakikatnya memandang kebijakan publik sebagai kelanjutan dari kegiatan-kegiatan yang telah dilakukan oleh pemerintah di masa lampau, dengan hanya melakukan perubahan-perubahan seperlunya.Model inkremental ini untuk pertama kalinya dikembangkan oleh Charles E. Lindblom, sebagai kritik terhadap model rasional komprehensif dalam pembuatan kebijakan publik. Pendukung model ini menyatakan bahwa perubahan tambahan lebih cepat dari perubahan komprehensif bahwa potensi konflik jauh lebih rendah dibandingkan dengan perubahan radikal dan inkremental adaptasi kontribusi pada redefinisi kebijakan secara terus menerus. Model ini pada hakikatnya memandang kebijakan publik sebagai kelanjutan dari kegiatan-kegiatan yang telah dilakukan oleh pemerintah dimasa lampau, dengan melakukan perubahanperubahan seperlunya.

Model ini mencerminkan sebagai suatu Model pengambilan keputusan yang menghindari banyak masalah yang harus dipertimbangkan. Selain itu Model ini juga merupakan Model yang lebih banyak menggambarkan cara yang ditempuh oleh pejabat-pejabat pemerintah dalam mengambil keputusan sehari-hari. Uraian mengenai model ini, dicetuskan oleh Charles E. Lindblom dalam bukunya yang berjudul "The Science of Muddling Through" dikutip dari (Islamy,1988:4.17) menjelaskan mengenai proses pembuatan keputusan dengan model yang disebut "disjointed incrementalism" atau disebut dengan model inkremental. Inkremental sendiri berarti kebijakan yang mengalami perubahan sedikit-sedikit. Model ini memandang kebijakan publik sebagai suatu kelanjutan kegiatan-kegiatan pemerintah dimasa lalu dengan hanya menambah atau merubahnya (modifikasi) sedikit-sedikit, yang berupaya untuk mengatasi kelemahan-kelemahan yang disandang dan dipikul oleh Model rasional komprehensif (kritik terhadap model rasionalitas komprehensif). Model ini melihat pemecahan suatu masalah dengan sudut pandang yang lebih realistik terhadap keterbatasanketerbatasan yang dimiliki oleh para pembuat kebijakan. 
Pendukung dari model ini menyatakan bahwa perubahan tambahan atau tambal sulam jauh lebih cepat dari perubahan yang bersifat komprehensif atau menyeluruh. Inkremental sendiri berarti kebijakan yang mengalami perubahan sedikit-sedikit. Hal yang paling mendasar dari model inkramental adalah adanya keterbatasan-keterbatasan yang ada dalam pembuat keputusan. model incremental ini hanya memusatkan perhatiannya pada modifikasi atas kebijakan yang ada sebelumnya.

Pokok Model inkremental ini yaitu:

1. Dalam hal pembuat keputusan, hanya mempertimbangkan beberapa altematif yang langsung berhubungan dengan pokok masalah.

2. Bagi tiap altematif hanya sejumlah kecil akibat-akibat yang mendasar saja yang akan dievaluasi.

3. Masalah yang dihadapi oleh pembuat keputusan akan didedifinisikan secara terarur.

4. Bahwa tidak ada keputusan atau cara pemecahan yang tepat bagi tiap masalah.

Pembuatan keputusan yang inkremental pada hakikatnya bersifat perbaikan-perbaikan kecil dan hal ini lebih diarahkan untuk memperbaiki ketidak sempunaan dari upaya-upaya konkrit dalam mengatasi masalah sosial yang ada sekarang dari pada sebagai upaya untuk menyodorkan tujuan-tujuan sosial yang sama sekali baru di masa yang akan datang.
Analisis dengan model inkremental ini memberikan jalan berbeda dari rasional-komprehensif (sinoptis), selain menawarkan kemudahan dalam analisis karena tidak perlu melakukan analisis secara cermat dan teliti, cukup melihat kebijakan yang telah ada kemudian disesuaikan dengan permasalahan yang terus berubah, cukup melakukan utakatik penyesuaian, hal tersebut sudah merupakan analisis. Kebijakan dibuat oleh perumus kebijakan tanpa harus melihat atau meneliti dengan komperehensif, sehingga dari alternatif yang ada secara singkat diputuskan untuk dijadikan kebijakan dan kegiatannya menjadi terus menerus, karena kebijakan yang dibuat tidak ada yang benar-benar untuk dijadikan pemecahan masalah secara keberlanjutan, hanya untuk masalah yang hadir sekarang.

Gambar 1. Model Kebijakan

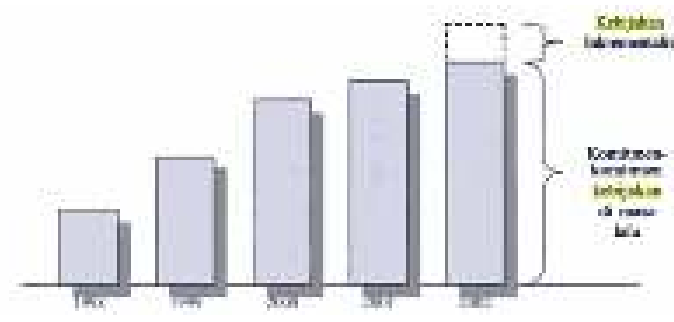

Kebijakan Model Inkrementalistik (Nugroho, 2006)
Dari gambar tersebut tampak bahwa kebijakan ini berusaha mempertahankan komitmen kebijakan di masa lalu untuk mempertahankan kinerja yang telah tercapai (Nugroho,2006:90) 
Menurut penulis model inkremental merupakan analisis sederhana ketika melihat masalah yang hadir cukup diteliti dipermukaan masalah, lihat kebijakan yang telah ada berikan sedikit perubahan untuk penyesuaian, maka jadilah sebuah kebijakan. Hal yang paling mendasar dari model inkramental adalah dari adanya keterbatasan-keterbatasan yang ada dalam pembuat keputusan, maka model inkremental hanya memusatkan perhatiannya pada modifikasi atas kebijakan yang ada sebelumnya.Model pembuatan kebijakan inkremental adalah yang paling cocok untuk masyarakat yang majemuk (pluralistic society) seperti Amerika Serikat.

Menurut pandangan kaum inkrementalis, para pembuat keputusan dalam menunaikan tugasnya berada di bawah keadaan yang tidak pasti yang berhubungan dengan konsekuensikonsekuensi dari tindakan mereka di masa depan, maka keputusan-keputusan inkremental dapat mengurangi risiko atau biaya ketidakpastian itu. Inkrementalisme juga mempunyai sifat realistis karena didasari kenyataan bahwa para pembuat keputusan kurang waktu, kecakapan, dan sumber-sumber lain yang dibutuhkan untuk melakukan analisis yang menyeluruh terhadap semua penyelesaian alternatif masalahmasalah yang ada. Disamping itu, pada hakikatnya orang ingin bertindak secara pragmatis, tidak selalu mencari cara hingga yang paling baik dalam menanggulangi suatu masalah. Singkatnya, inkrementalisme menghasilkan keputusan-keputusan yang terbatas, dapat dilakukan dan diterima.

Menurut Lindblom, di satu sisi, model inkremental bisa dianggap sebagai sebuah model deskriptif dalam pengeritan bahwa kebijakan yang dibuat melalui apa yang disebut sebuah proses "pemecahan" (a "muddling through"). Di lain sisi, model ini juga dipandang sebagai sebuah pendekatan yang secara mendasar konservatif terhadap policy innovation. Sekalipun model ini merupakan pembenaran yang canggih terhadap kebijakan dan proses pembuatan kebijakan yang mendasarkan pada "muddling through", yakni perubahan inkremental namun sulit untuk membenarkan menurut asumsi bahwa keputusan-keputusan kebijakan masa lalu adalah selalu benar, khususnya pada saat terjadi perubahan-perubahan yang sangat cepat, dan masalah atau persoalan yang sedang didiskusikan tidak mempunyai preseden.

Kelemahan model incremental adalah hanya dapat diambil ketika masalah yang dihadapi pembuat kebijakan public merupakan masalah rutin dan tidak dapat dilaksanakan untuk mengatasi masalah krisis (suwirtini,2009:40).

Pembuatan keputusan yang inkremental pada hakikatnya bersifat perbaikan-perbaikan kecil dan hal ini lebih diarahkan untuk memperbaiki ketidak sempurnaan dari upaya-upaya konkrit dalam mengatasi masalah sosial yang ada sekarang dari pada sebagai upaya untuk menyodorkan tujuan-tujuan 
sosial yang sama sekali baru di masa yang akan datang.

Model inkremental ini bersifat pragmatis, tidak bermaksud mencari pilihan kebijakan yang terbaik, melainkan sekedar mencari alternatif yang dapat dilaksanakan. Namun, Model ini bukan berarti tak terlepas sama sekali dari kelemahan, bila dipraktekkan memang benar dalam banyak kasus, pengambil keputusan tehadap suatu kebijakan untuk menyelesaikan suatu masalah publik, enggan melakukan perombakan total terhadap kebijakan yang sedang berjalan. Tetapi juga berbahaya bila selalu menyarankan kepada perubahan yang bersifat inkremental, ketika secara keseluruhan kebijakan yang tengah berjalan, tidak dapat dipertahankan lagi. Perubahan secara mendasar, acapkali justru menjadi tuntutan dari pengambil kebijakan, terutama ketika terjadi pergantian rejim pemerintahan. Walaupun tidak dalam pergantian rejim, perombakan total atau komprehensip perlu dilakukan ketika kebijakan yang sedang berjalan tidak mungkin dipertahankan.

Meskipun pembuatan keputusan yang inkremental pada hakikatnya bersifat perbaikan-perbaikan kecil. Namun Model inkremental ini kemudian dikritik karena kurang memperhatikan orientasi tujuan. Model inkremental akan membuat berbagai persimpangan berulang-ulang tanpa mengetahui kemana tujuan yang akan dicapai. Model ini dikritik karena kecenderungan inherennya pada konservatisme, terlalu pesimis terhadap perubahan bersekala besar dan inovasi. Selain itu, model inkremental ini dikritik karena dianggap tidak demokratis, sebab terlalu membatasi pengambilan keputusan yang hanya pada tawar menawar sekelompok kecil orang-orang pilihan, para pembuat kebijakan senior.

Model ini juga dianggap mendorong munculnya keputusan-keputusan berdasarkan perhitungan jangka-pendek, yang dikawatirkan akan menimbulkan konsekuensi negatif terhadap jangka panjang. Sebagai tambahan, model ini juga dikritik karena hanya memiliki kemampuan analitis yang sempit. Contohnya, mencatat bahwa inkremental hanya bisa bekerja ketika ada kontinyuitas problem dalam jangka waktu yang cukup panjang, yang mana problem ini berusaha diselesaikan melalui suatu kebijakan tertentu. Model ini juga mensyaratkan cara yang dibutuhkan untuk menjalankan kebijakan tersebut hampir selalu bisa dipakai. Pada kenyataannya, syarat-syarat ini jarang sekali terpenuhi. Inkrementalisme juga memiliki karakteristik sebagai model pengambilan keputusan dalam sebuah lingkungan yang relatif stabil, dan agak sulit untuk diaplikasikan pada situasisituasi tidak biasa, seperti krisis.

Ada beberapa kelemahan dalam Model inkremental ini diantaranya adalah, keputusan-keputusan yang diambil akan lebih mewakili atau mencerminkan kepentingan dari kelompok yang kuat dan mapan sehingga kepentingan dari kelompok yang lemah 
terabaikan dan diduakan. Keputusan diambil lebih ditekankan kepada keputusan jangka pendek dan tidak memperhatikan berbagai macam kebijakan lain sehingga pengambilan keputusan yang bersifat inkremental tidak mampu menjadi solusi atas permasalahan publik. Dinegara berkembang Model ini tidak cocok untuk diterapkankarena perubahan yang bersifat inkremental tidak tepat karena negara berkembang lebih membutuhkan perubahan yang besar dan mendasar. Menurut Yehezkel Dror(1968) model inkremental dalam membuat keputusan cenderung mengahasilkan kelambanan dan terpeliharanya status quo, sehingga perubahan tidak cepat dan tidak signifikan.

\section{Pembahasan}

Berbagai keraguan tentang praktikalitas bahkan kegunaan model rasional membawa pada usaha untuk mengembangkan sebuah teori pengambilan keputusan yang lebih dekat dalam memperkirakan perilaku aktual dari para pengambil keputusan. Situasi ini mendorong munculnya model inkremental yang memotret pengambilan keputusan kebijakan publik sebagai sebuah proses yang dikarakterisasikan oleh tawar menawar dan kompromi antara berbagai pengambil keputusan yang memiliki kepentingannya sendirisendiri. Keputusan-keputusan yang dihasilkan tentu saja lebih merepresentasikan apa yang secara politik fisibel dari pada diinginkan.

Jasa dalam mengembangkan model inkremental dalam analisa pengambilan keputusan kebijakan publik paling layak diatributkan pada ilmuwan politik Yale University, Charles Lindblom. Ia merangkum model ini sebagai sebuah model yang terdiri dari strategi-strategi yang saling mendukung dalam melakukan penyederhanaan dan pemusatan fokus. Strategi-strategi itu adalah:

- Pembatasan analisis hanya pada beberapa alternatif kebijakan yang familiar...hanya sedikit berbeda dari status quo;

- Sebuah analisis tujuan kebijakan yang berjalinkelindan dan nilai-nilai dengan berbagai aspek empiris dari masalah yang dihadapi

- Sebuah strategi yang mengedapankan analisis untuk mencari masalah yang ingin diselesaikan daripada tujuan-tujuan positif yang ingin dikejar;

- Serangkaian percobaan, kegagalan, dan percobaan ulang;

- Analisis yang mengeksplorasi hanya sebagian, bukan keseluruhan, konsekuensi-konsekuensi yang penting dari suatu alternatif yang dipertimbangkan;

- Fragmentasi kerja analitis untuk berbagai partisipan dalam pembuatan kebijakan (setiap partisipan mengerjakan bagian mereka dari keseluruhan domain). 
Dalam pandangan Lindbolm, para pengambil keputusan mengembangkan berbagai kebijakan melalui sebuah proses membuat 'perbandingan terbatas yang berurutan dengan kebijakan sebelumnya', yaitu keputusan-keputusan yang sudah familiar bagi mereka. Seperti dikemukakan dalam artikelnya yang telah banyak dikutip, 'The Science of "Muddling Through"', para pengambil keputusan bekerja dalam sebuah proses yang secara terus menerus 'terbangun dari situasi yang ada pada saat itu, setapak-demisetapak dan dalam derajad yang kecil'. Keputusan yang diambil biasanya hanya sedikit berbeda dari keputusankeputusan yang sudah ada; dengan kata lain, perubahan dari status-quo bersifat inkremental.

Ada dua sebab mengapa berbagai keputusan cenderung tidak terlalu jauh berbeda dengan status quo.

1. Karena proses tawar menawar mensyaratkan distribusi sumber daya yang terbatas di antara berbagai partisipan, maka akan lebih mudah untuk melanjutkan pola distribusi yang sudah ada daripada membuat sebuah pola baru yang berbeda secara radikal. Keuntungan dan kelemahan dari tatanan ada sudah diketahui dan dikenal oleh para aktor kebijakan, berbeda dengan ketidakpastian yang melingkupi tatanan yang masih baru, yang membuat kesepakatan untuk melakukan perubahan menjadi sulit dicapai. Hasil yang memiliki kemungkinan lebih besar untuk muncul adalah kelanjutan dari status quo atau hanya perubahan kecil dari status quo.

2. Standard operating procedure yang menjadi batu penjuru seluruh sistem birokrasi cenderung untuk lebih mengedepankan keberlanjutan atau kontinyuitas praktek-praktek yang sudah ada. Cara para birokrat mengidentifikasi berbagai opsi, metode dan kriteria untuk dipilih seringkali telah ditetapkan lebih dahulu, menghambat inovasi dan hanya mengulang tatanan yang sudah ada.

Lindbolm juga berpendapat bahwa model inkremental yang mensyaratkan pemisahan antara tujuan dan cara ternyata tidak bisa dipraktekan dalam praktek, tidak hanya karena ada batasan waktu dan informasi seperti yang dikatakan Simon, tetapi juga karena para pembuat kebijakan tidak pernah benarbenar bisa memisahkan antara tujuan dan cara. Lindbolm berpendapat bahwa di sebagian besar area kebijakan, tujuan tidak bisa dipisahkan dari cara, dan tujuan apa yang dituju seringkali bergantung pada efektifitas cara yang tersedia untuk mencapai tujuan tersebut. Karena kesepakatan atas pilihan kebijakan sulit untuk dicapai, para pengambil keputusan menghindari membuka kembali isu-isu lama atau mempertimbangkan kembali pilihanpilihan yang terlalu jauh berbeda dengan praktek-praktek yang ada, karena membuat kesepakatan menjadi semakin 
sulit dicapai. Hasilnya adalah berbagai keputusan kebijakan yang hanya sedikit berbeda dengan kebijakan-kebijakan terdahulu.

Model inkremental melihat pengambilan keputusan sebagai sebuah kegiatan praktis yang berfokus pada pemecahan masalah yang sedang dihadapi daripada berupaya mencapai tujuan jangka panjang. Dalam model ini, cara-cara yang dipilih untuk menyelesaikan masalah ditemukan melalui trial-and-error dari pada melalui evaluasi yang komprehensif dari semua cara yang ada. Para pengambil keputusan hanya mempertimbangkan beberapa alternatif yang familiar, dan dianggap pantas, dan berhenti mencari alternatif lain ketika mereka percaya bahwa sebuah alternatif yang bisa diterima telah ditemukan.

Dalam tulisan sebelumnya, Lindbolm dan para koleganya berkeyakinan bahwa kemungkinan pengambilan keputusan secara inkremental sangat mungkin adabersama dengan upaya-upaya untuk mencapai keputusan secara lebih rasional. Dengan demikian, Braybrooke dan Lindbolm berpendapat bahwa empat tipe pengambilan kuputusan bisa digunakan tergantung pada pengetahuan yang dimiliki oleh para pengambil keputusan, dan seberapa besar perbedaan alternatif kebijakan dengan kebijakan yang sudah ada. Ini memunculkan matix yang ditunjukan sebagai berikut:
Tabel 1. Empat Tipe Pengambilan Keputusan

\begin{tabular}{|l|c|c|c|}
\hline \multicolumn{2}{|c|}{} & \multicolumn{2}{c|}{ Tingkat pengetahuan } \\
\cline { 2 - 4 } \multicolumn{2}{|c|}{} & Tinggi & Rendah \\
\hline $\begin{array}{l}\text { Perbedaan } \\
\text { yang ada } \\
\text { antara } \\
\text { kebijakan } \\
\text { alternatif } \\
\text { dan yang } \\
\text { terdahulu }\end{array}$ & Tinggi & Revolusioner & Analitis \\
\cline { 2 - 4 } & Rendah & Rasional & $\begin{array}{c}\text { Inkremental, } \\
\text { terpisah- } \\
\text { pisah } \\
\text { (disjointed } \\
\text { incremental) }\end{array}$ \\
\hline
\end{tabular}

Sumber: diadaptasi dari David Braybrooke dan Charles Lindblom, 1963.

Dalam pandangan ini, sebagian besar keputusan nampaknya diambil secara incremental, melibatkan perubahan yang sangat kecil dalam situasi di mana hanya tersedia sedikit informasi dan pengetahuan. Tetapi, ada tiga kemungkinan lain, model rasional muncul sebagai salah satu kemungkinan bersama-sama dengan dua tipe yang definisinya tidak terlalu jelas revolusioner dan analitis - dan tidak terlalu sering digunakan sebagai alternatif pengambilan-keputusan.

Dalam perjalanan karir selanjutnya, Lindblom berpendapat bahwa ada spektrum style pengambilan keputusan. Spektrum ini terentang dari kutub 'synoptic' atau komprehensif rasional sampai pada 'blundering', yang artinya hanya mengikuti perkiraan-perkiraan tanpa ada upaya riil yang sistematis untuk menganalisa berbagai strategi alternatif. Spektrum itu diilustrasikan sbb.:

Gambar.2 Spetrum Berbagai Style Pengambilan Keputusan 

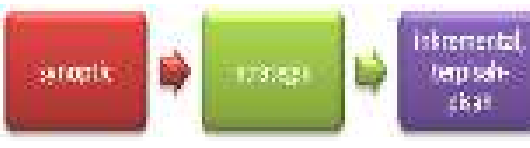

ibreneral

2tratsis

Meskipun menerima berbagai kemungkinan teoritis bagi berbagai styles pengambilan keputusan, Lindbom dalam karya-karyanya yang kemudian menolak seluruh alternatif lain bagi model incremental berdasarkan alasan-alasan praktis. Ia berpendapat bahwa setiap analisis sinotik yang berusaha untuk mencapai keputusan-keputusan berdasarkan berbagai kriteria berorientasi maksimalisasi akan berakhir dengan kegagalan, dan seluruh pengambilan keputusan didasarkan pada, apa yang disebutnya sebagai, analisis 'yang tidak lengkap dan tergeneralisasi' (grossly incomplete analysis). Lindblom berpendapat, esensi dari inkrementalism adalah untuk mensistematisasikan berbagai keputusan yang dicapai melaui cara ini, dengan menekankan pada pentingnya mencapai kesepakatan politik dan belajar dari trial-and-error, ketimbang hanya berkutat dengan keputusan-keputusan secara acak.

Jika model inkremental mungkin bisa memberikan deskripsi yang akurat yang mana klaim ini juga debatable tentang bagaimana keputusan kebijakan publik seringkali dibuat, para kritikus ternyata juga menemukan beberapa kesalahan sebagai implikasi dari alur penelaahan yang disarankan model ini.
Pertama, model ini dikritik karena sangat kurang memperhatikan orientasi tujuan. Schagaimana dilontarkan oleh Fosters, inkementalisme 'akan membuat kita meintasi berbagai persimpangan br:ulang-ulang tanpa mengetahui ke»lana kita tujuan kita'. Kedua, model ini dikritik karena kecenderungan inherennya pada konservatisme, terlalu pesimis terhadap perubahan bersekala besar dan inovasi. Ketiga, model ini dikritik karena dianggap tidak demokratis, karena membatasi pengambilan keputusan hanya pada tawar menawar sekelompok kecil orangorang pilihan, para pembuat kebijakan senior. Keempat, dengan tidak memperhatikan analisis dan perencanaan yang sistematik dan, sedikit banyak, menegasi kebutuhan untuk mencari alternatif-alternatif baru, model ini dianggap mendorong munculnya keputusan-keputusan berdasarkan perhitungan jangka-pendek, yang dikawatirkan akan menimbulkan konsekuensi-konsekuensi negatif jangka panjang. Sebagai tambahan, model ini juga dikritik karena hanya memiliki kemampuan analitis yang sempit. Yehezkel Dror, contohnya, mencatat bahwa inkrementalism hanya bisa bekerja ketika ada kontinyuitas problem dalam jangka waktu yang cukup panjang, yang mana problem ini berusaha diselesaikan melalui suatu kebijakan tertentu.

Model ini juga mensyaratkan cara yang dibutuhkan untuk menjalankan kebijakan tersebut hampir selalu bisa 
dipakai. Pada kenyataannya, syarat-syarat ini jarang sekali terpenuhi. Inkrementalisme juga memiliki karakteristik sebagai model pengambilan keputusan dalam sebuah lingkungan yang relatif stabil, dan agak sulit untH Huk diaplikasikan pada situasi-situasi tidak biasa, seperti krisis.

\section{TEORI PENDUKUNG}

\section{Waterfall Model}

Pendekatan suatu pengembangan sistem yang sederhana, lebih dikenal sebagai model air terjun (waterfall model). Model air terjun ini mendeskripsikan alur proses pengembangan sistem informasi seperti tampak pada Gambar 3.

Gambar 3. Metode Waterfall dalam Kebijakan Publik.

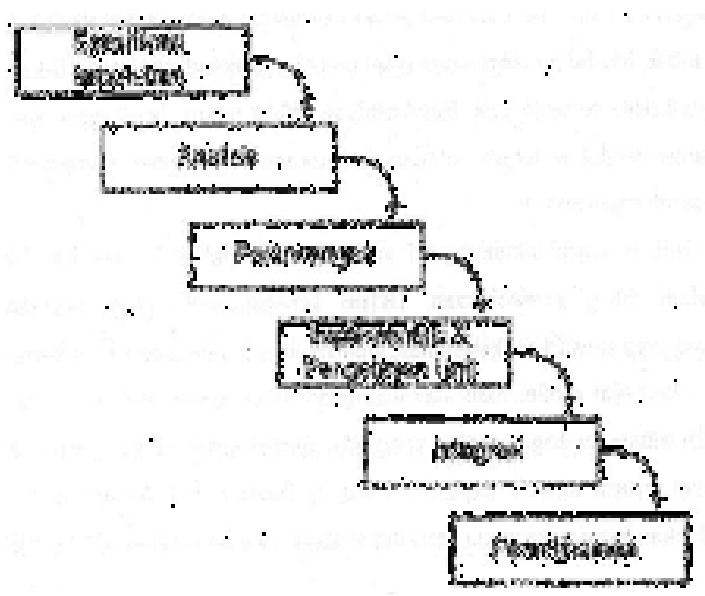

Pekerjaan pengembangan sistem dengan model air terjun dimulai dengan pembuatan spesifikasi kebutuhan suatu sistem. Pekerjaan ini biasanya dilakukan oleh orang yang memesan sistem atau pengembang yang bekerja sama dengan pemesannya. Setelah spesifikasi kebutuhan ini selesai, lantas dilakukanlah suatu analisis dan deskripsi logika sistem. Atau, analisis dan deskripsi logika sistem dibuat secara bersama-sama dengan spesifikasi kebutuhan.

Rancangan sistem kemudian diselesaikan dan diikuti dengan implementasi modul yang lebih kecil. Modul-modul ini pertama-tama diuji secara sendiri-sendiri dan kemudian secara hersama-sama. Ketika pengujian integrasi terakhir telah diselesaikan, keseluruhan sistem dapat diserahkan ke pemakai serta dimulailah tahap pemeliharaan.

Model air terjun ini memberi penekanan bahwa seseorang harus menyelesaikan suatu tahap sebelum masuk ke tahap berikutnya. Model air terjun ini telah memberikan pengaruh besar pada metode rekayasa

perangkat lunak. Model ini sebenarnya tidak pernah dimaksudkan untuk dilaksanakan secara kaku pada saat pertama kali diperkenalkan. Akan tetapi, belakangan disadari bahwa model air terjun ini harus direvisi agar benar-benar menggambarkan siklus pengembangan sistem.

\section{Contoh Kasus}


Contoh kasus kebijakan publik yang menerapkan model inkremental adalah kebijakan publik dalam bidang pendidikan. Mengikuti pola ilmu pengetahuan yang selalu berkembang Pemerintah melalui kementrian pendidikan dan kebudayaan disetiap beberapa tahun sekali selalu mengubah kurikulum pendidikan nasional. Perubahan dunia secara global menuntut materi pendidikan Indonesia yang digodok dalam bentuk kurikulum harus memperbaharui materi pengajarannya. Hal ini dengan tujuan untuk mencapai pengaruh yang maksimal terhadap anak didik secara nasional.

Perubahan kurikulum yang dilakukan terus menerus tersebut merupakan sebuah contoh untuk model inkremental. Hal ini dikarenakan karakteristik dan metode peninjauan yang dilakukan sesuai dengan penjelasan mengenai karakteristik dan metode evaluasi dalam model inkremental.

Selain itu terdapat orientasi nilai yang terjadi dalam penetapan kurikulum baru. Disetiap perancangan dan pembuatan kurikulum baru melibatkan APBN anggaran pendidikan. Pada tahun 2016 ini anggaran pendidikan dalam APBN 2016 mencapai Rp 419,2 triliun atau 20 persen dari total belanja negara Rp 2095,7 triliun. Selain itu untuk merubah kurikulum yang lama pada tahun ini pemerintah juga melibatkan sumber dana lain sebagai penunjuang susksesnya pengadaan kurikulum baru. Diantaranya melalui Daftar Isian Pelaksanaan Anggaran (DIPA) pusat, bantuan operasional sekolah (BOS), dan dana alokasi khusus (DAK). Pos-pos anggaran itu akan difokuskan untuk penggandaan buku dan pelatihan guru.

Saat ini pemerintah masih menerapkan kurikulum 2006 atau yang lebih dikenal dengan Kurikulum Tingkat Satuan Pendidikan (KTSP) sebagai pengganti sementara Kurikulum 2013 yang dinilai bermasalah. Berdasarkan kebijakan ini kemudian penulis mencoba untuk membuat alternatif kebijakan inkremental untuk desain kurikulum selanjutnya.

Desain kurikulum pendidikan selama ini menurut penulis sudah sangat jauh keluar dari niat awal dibangunnya sistem pendidikan dunia saat ini yang dikenal dengan sekolah. Sekolah awalnya bertujuan untuk meningkatkan bakat yang dimiliki oleh seorang murid atau siswa. Dengan melihat bakat alami yang dimiliki sekolah kemudian diasosiasikan sebagai tempat untuk menempa bakat yang telah ada dalam diri.

Namun demikian seiring waktu beberapa negara termasuk Indonesia justru melenceng dalam pelaksanaan pendidikan yang baik. Setiap siswa atau murid saat ini diajarkan berbagai mata pelajaran atau ilmu pengetahuan bahkan yang tidak disenangi untuk dikuasai. Padahal dalam hakikatnya seorang murid kemungkinan hanya akan maju dengan pesan dalam satu atau dua bidang ilmu pengetahuan. Semisal, seorang yang pandai matematika cenderung tidak beitu panda dalam ilmu sastra dan seni. Begitu pun sebaliknya. 
Pola penilaian bakat siswa dari sekolah dan dari dunia sosial memacu siswa untuk meninggalkan bakatnya dan berlomba-lomba mencari nilai terbaik dalam sebuah bidang ilmu yang dipelajari. Yang pada akhirnya dia hanya akan mempraktekkan satu atau dua pelajaran yang dia dapatkan disekolah. Sangat banyak masalah dalam sistem pendidikan Indonesia saat ini terutama dalam hal kurikulum yang menurutt penulis dibuat hanya untuk memperparah sistem pendidikan yang ada.

Penulis kemudian mendesai sebuah kebijakan dalam model inkremental di bidang pendidikan melalui kurikulum dengan metode sebagai berikut. 1 . Penilaian ditujukan hanya pada satu atau dua bidang ilmu yang dikuasai oleh siswa. 2. Kurikulum didesain untuk memancing bakat siswa yang sudah ada sejak dia lahir. 3. Menghilangkan ujian nasional sebagai bentuk diskriminasi bagi kemampuan siswa. 4. Mengutamakan pendidikan moral dalam kehidupan berbangsa dan bernegara.

Jika dilihat dari kajian ilmu komunikasi, pembuatan kurikulum pendidikan tidak dapat dibuat tanpa memperhatikan efek dari kurikulum yang hendak dibuat. Untuk itulah, pesan dalam kurikulum yang diterapkan dalam bentuk buku pengajaran kemudian diharapkan mampu memberikan dampak positif bagi pengetahuan dan pemahaman siswa baik dari segi psikomotof, afektif dan kognitifnya. Dalam proses inilah ilmu komunikasi bekerja. Para ahli dituntut untuk mampu mendesain pesan dalam kurikulum agar mudah dimengerti oleh anak didik dan dapat memberikan perubahan yang besar bagi pengetahuan dan pemahaman siswa.

\section{Kesimpulan}

Berdasarkan diskurus diatas, Secara sederhana Model Inkremental dapat dinyatakan sebagai sebuah model kebijakan yang dilakukan dengan mendesain ulang kebijakan yang ada namun masih dalam koridor rangka utama kebijakan asalnya. Model Inkremental dilakukan untuk menghadapi masalah yang membutuhkan penanganan dengan waktu yang cukup singkat. Perubahan kurikulum pendidikan di Indonesia menerapkan model inkremental dalam penetapannya.

\section{Daftar Pustaka}

Edi Suharto (2008), Analisis Kebijakan Publik. CV Alfabeta. Bandung.

Islamy, M.Irfan (1988) Materi Pokok Kebijakan Publik. Jakarta; Universitas Terbuka.

Dunn William N. (2001) Analisis Kebijakan Publik. Yogyakarta.

Robert A. Dahl \& Charles E. Lindblom, (1953) Politics, Economics And Welfare: Planning And Politico-Economic Systems Resolved Into Basic Social Processes. New York: Harper And Row.

Charles E. Lindblom (1955), Bargaining. Los Angeles: Rand Corporation. 
Charles E. Lindblom, 'The Science of Muddling Through', Public Administration Review 19, 2, 1959: 79-88;

Charles E. Lindblom, 'Policy Analysis', American Economic Review 48, 3, 1958: 298-312.

Charles E. Lindblom, 'Still Muddling, Not Yet Through', Public Administration Review 39, 6, 1979: 517.

Harold Gortmer, Julianne Mahler \& Jeanne Bell Nicholson, (1987). Organization Theory: A Public Perspective. Chicago: Dorsey Press.

David Braybrooke \& Charles Lindblom (1963), A Strategy Of Decision: Policy Evaluation As A Social Process. New York: Free Press Of Glencoe.

Charles E. Lindblom \& D.K. Cohen (1979), Usable Knowledge: Social Science And Social Problem Solving. New Haven: Yale University Press.

Andrew Weiss \& Edward Woodhouse, 'Reframing Incrementalism: A Constructive Response to Critics', Policy Sciences 25, 3 (1992): 255-73.

John Forester, 'Bounded Rationality and the Politics of Muddling Through', Public Adminstration Review 44, 1 (1984): 23.

Louis Gawthrop (1971). Administrative Politics and Social Change. New York: St. Martin's Press.

Yehezkel Dror, 'Muddling Through"Science" or Inertia', Public Administration Review 24, 3 (1964): 154-7.
D.C. Nice, 'Incremental and Nonincremental Policy Responses: The States and the Railroads', Polity 20 (1987): 145:56. 